\title{
PROSPECTS
}

\section{Balancing belief and bioscience}

Can religious belief really be reconciled with a life in science? Gene Russo contemplates the contradictions.

The recent nomination of Francis Collins to direct the US National Institutes of Health does more than raise the question of the agency's future direction. It poses another question. Can a scientific career go hand in hand with religious belief? Put another way, can a great scientist be deeply religious?

Collins is well known as one of the architects of the Human Genome Project. He has also achieved notoriety as a highly respected scientist with deepseated religious beliefs. An evangelical Christian since the age of 27, Collins detailed his views on reconciling religion and science in his 2006 book The Language of God: A Scientist Presents Evidence for Belief.

The obvious reply to the suggestion of conflict is that religious belief can coexist perfectly well with scientific laws and methods - God simply exists outside nature. In Collins's book, for example, he calls himself a believer in "theistic evolution" - which espouses, in part, that "once evolution got under way no special supernatural intervention was required".

Yet theistic evolution, writes Collins, also implies that humans are unique in ways

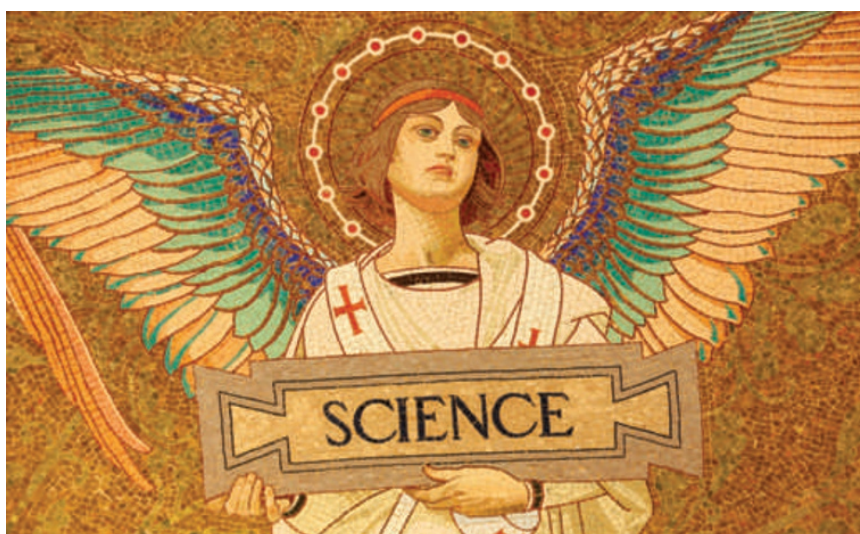

Center, found that figure to be $33 \%$. But in a second survey ${ }^{3}$, Larson and Witham asked a slightly different question. Do leading scientists have religious faith of equal measure to scientists in general? They used members of the US National Academy of Sciences for their so-called "greater scientist" subgroup. Just $7 \%$ of respondents professed a belief in God.

University of Oxford chemist Peter Atkins assessed the Larson and Witham survey results in this way: "You clearly can be a

that "defy evolutionary explanation and point to our spiritual nature". And in a 2006 Time magazine debate with noted atheist and evolutionist Richard Dawkins ${ }^{1}$, Collins suggested that God could on rare occasions choose to "invade the natural world in a way that appears miraculous" - a peculiar outlook for a biologist.

How rare is a 'dual practitioner' such as Collins? In 1997, University of Georgia history professor Edward Larson and journalist Larry Witham reported survey results suggesting that $39 \%$ of scientists believe in $\mathrm{God}^{2}$. A 9 July 2009 survey, conducted by the American Association for the Advancement of Science and the US non-profit Pew Research scientist and have religious beliefs. But I don't think you can be a real scientist in the deepest sense of the word because they are such alien categories of knowledge." Eminent Harvard University psychologist Steven Pinker, in criticizing the Collins nomination, said much the same thing ${ }^{4}$. They may be right. Or perhaps it just takes a rare person to advance a scientific career while balancing belief and bioscience - without corrupting either. Gene Russo is editor of Naturejobs.

1. www.time.com/time/magazine/article/ 0,9171,1555132,00.html.

2. Larson, E. J. \& Witham, L. Nature 386, 435-436 (1997)

3. Larson, E. J. \& Witham, L. Nature 394, 313 (1998).

4. Nature 460, 310-311 (2009).

\section{California scrambles to find money for pay}

With draconian budget cuts already driving out top researchers at the University of California (UC), senior scientists are scrambling to find new revenue sources in the face of a university plan to impose unpaid leave and cut pay.

On 16 July the UC board of

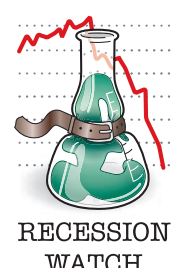

accept more out-of-state students. "We have to cut loose from the state of California and come up with a new revenue model," she says, pointing to the University of Michigan as a successful example of an institution that does not rely overwhelmingly on in-state students for tuition revenue: about a third of that university's regents voted to empower university president Mark Yudof to force employees to take unpaid leave. The furloughs would range from 11 to 26 days and amount to salary cuts of $4-10 \%$, intended to accommodate cuts in state funding. The university expects these cuts to total US $\$ 813$ million, thanks to the state's \$26-billion budget deficit. At press time, several faculty members were known to be leaving as a result (see Nature 460, 441; 2009). UC has 108,000 full-time employees.

Solutions, however, are hard to come by. According to Sandra Faber, chair of the astronomy department at the University of California, Santa Cruz, the university could undergraduates came from outside Michigan. Conversely, in the 2007-08 school year, 91\% of UC students were from California, according to university website data.

George Blumenthal, chancellor of the University of California, Santa Cruz, suggests raising in-state student fees as a means of boosting revenue. "To the extent we are supported by the state, we have an obligation to provide access [to in-state students]," he says. "To the extent that support is drying up, we have to [change that model]."

Continuing with the current funding strategy for more than a year will imperil the reputation and calibre of $U C$, according to Faber. "The faculty will evaporate and the university will collapse," she says. "The university has one year's grace period. After that, these [early-and mid-career] people will leave, and replacing them with people of the same calibre is hopeless. We will have lost our brand name."

Despite the departures of faculty members, some say things could be worse. "Recruitment and retention would be more of a concern if the rest of the world weren't also in a terrible economic recession," says Kevin Woolfork budget policy coordinator at the California Postsecondary Education Commission, the planning and coordinating body for higher education in the state.

UC receives about $\$ 3$ billion annually from the state and earns much of the rest of its revenue from its research grants and hospitals. Its total annual budget is about $\$ 19$ billion, according to the university website.

Karen Kaplan 